\title{
MOTIVE OR REASON IN CRIMINAL LAW
}

\author{
Elisabeta BOȚIAN \\ Romanian-German University of Sibiu, Sibiu, Romania \\ elisabeta.botian@roger-univ.ro
}

\begin{abstract}
Guilt often encompasses volitional and intellectual mental processes and only in rare cases it will include affective processes. The motive and purpose are certain mental processes which the legislator sometimes introduces in the content of the offenses. The motive is the psychological causal support of human facts. The doctrine currently uses both the term of motive and that of reason, but the Criminal Code uses exclusively the term motive, which better communicates the conscious and rational character of these psychological processes. In the general section of the Criminal Code, mental processes of the motive are common among the general criteria of punishment individualization and also in listing the aggravating circumstances. In the special part of the Criminal Code mental processes of the motive can be found both for typical or special variants and aggravated or qualifying forms of certain crimes. Motive can be expressed explicitly by equivalent terms or by an implied manner, which entails the need for interpretation of the text.
\end{abstract}

\section{Keywords: guilty, motive, purpose, crime content}

\section{Introduction}

In criminal law, guilt is defined by the correlation between the wrongful act and its author. The two concepts with which guilt is explained in the science of criminal law are normative theory and psychological theory. This latter view has been endorsed both by the Criminal Code of 1968, as well as that of 2009 (entered into force on February $\left.1^{\text {st }} 2014\right)$.

While according to normative theory, guilt appears as a reproach that society makes the individual about how he has acted, violating the rule of law, in psychological theory guilt is presented as a set of mental processes that highlight the connection between deed and its author.

This set of mental processes consists mainly of volitional and intellectual mental processes and only in rare cases it will include affective processes. Thus, the intent and guilt with the detailed rules, but also the overcome intention are actually certain mental processes selected by the legislator from the plurality of mental processes specific to humans that best highlight the conscious and deliberate character of the deed, as well as the attitude of the offender to the result of the deed.

As noted, most often, criminal law exploits in terms of guilt, mental processes that are most frequently encountered, but not excluded from cases in which the legislator attaches importance to other mental processes such as premeditation, bad faith, some mental disorder states or affective mental processes. Among the latter we can include motive and purpose, constituting the emotional support of criminal offences [1]. Unlike intent, guilt and exceeded intent that the legislator defines in the general part of the Criminal Code, the motive and purpose are not defined, however, they sometimes appear in the content of incrimination rules and determine certain legal consequences. 


\section{Terminology and Psychological Considerations}

I appreciate that achieving a more comprehensive analysis of the mental processes that make up the motive or the reason, the offense has to start from elucidating the etymology and meaning of these terms. According to the Dictionary of neologisms [2], by "motive" we understand the determining cause of an action, posing as synonymous for "reason". The word is of French origin (mobile), and in this language it may also mean, as a noun, cause, reason or grounds.

"Reason" is defined as that cause that determines an action or a feeling. As synonymous terms, there are mentioned the cause or pretext. The origin of the term is Latin, and in this language, "motivus" is the one that gives it meaning.

Analysing the causes of human crime, an important step is to identify the causative psychological support of delinquent behaviour. From this point of view there must be clarified both the reasons which led to some criminal behaviour and the goals or results by committing the illegal act.

By elucidating the motivation of the criminal act, judicial psychology tries to refocus the subject in the motivational plan to achieve its social recovery.

Criminology operates with the notions of motive and reason to highlight the genesis of criminal behaviour and the shift to delinquent act.

In terms of criminal doctrine, the notions of motive and reason were taken from psychological and criminological theories of the criminal act. In the beginnings of forensic psychology, both concepts were used, the motive being considered synonymous with reason. By motive or reason it was understood that what unleashes, supports and directs a certain activity. Subsequently, the term "motive" was used to refer to those emotional processes, predominantly unconscious and irrational, and the term "reason" was used for mental processes where the rational, conscious factor was predominant.

Currently, in modern psychological and criminological theories there is the tendency to abandon the classic notion of motive, in favour of reason, which is considered more comprehensive [1].

\section{Motive and Reason in the Doctrine of Criminal Law}

In Criminal Law, motive (or reason) and purpose are the affective mental processes that complement the sentimental framework of crimes and which, once identified, clarifies the deeper aspects of psychological processes that make up the guilt.

In terms of the sense in which they are used, the terms "motive" and "reason" are considered synonymous for most of the criminal doctrine and have the significance of a psychological process which represents the internal cause of the conduct act.

Analysing and planning the definitions given to motive / reason in the literature, we can distinguish two main trends, namely: the first is the one attributing motive the single significance of affective mental process generator of the criminal act, and the second considers that the motive comprises besides the emotional component other volitional and intellectual mental processes by which the perpetrator decides on the criminal act and decides on its implementation.

We have already stated that the legislation makes no conceptual distinction between motive and reason, and the current Criminal Code uses only the term "reason", without defining it, but in recent literature, we can see that the perpetrators of criminal further use, both the term "motive" and that of "reason". The simultaneous and undifferentiated use of the two terms were alleged to perpetrators of criminal law [3], but it should not be overlooked that the assessment of a specific mental process in the science of criminal law may be different from the assessment made by other disciplines. 
As far as we are concerned, we consider that, in order to avoid confusion, the use of term "reason" is advisable to be used, for at least two reasons.

The first argument is the expression of the legislator that, in the Criminal Code entered into force on February $1^{\text {st }}, 2014$, uses exclusively the term "reason". Thus, it is necessary and justified that the doctrine uses the terminology preferred by the legislator, as long as misuses or imprecise uses of those notions go unnoticed misuse.

The second argument considers the trends already highlighted in the forensic psychology and contemporary criminology, according to which "reason" means the conscious emotional and rational affective mental processes causing the individual to commit a crime. In this context it must be stressed that only the mental processes of conscious and rational order can have a criminal significance, being the sentimental binder between offence and author. For criminologists and psychologists, unconscious and affective factors that led the subject to commit a criminal offense may be relevant, therefore its motive, but the criminal law only assesses the volitional and intellectual mental processes.

\section{Reason in the Criminal Code in Force 4.1. General Part of the Criminal Code}

The term "reason" is found primarily in the general section of the Criminal Code, specifically in art. 74 dedicated to general criteria of punishment individualization, and par. 1 letter $d$ mentions the reason for committing the crime and the purpose.

The doctrine [4] emphasized that these mental elements could be appreciated in determining the sanction, only to those crimes whose contents do not already include these requirements, as constituent trait or circumstantial element, since they were taken into consideration in a specific sense when formulating the indictment. We believe, however, that it would be possible to take account of the mental processes of reason within the meaning of art. 74 letter d, for those offenses that include in the content of indictment only the requirement of the purpose, as the influence of the purpose might be retained in the case of indictments that include the essential requirement of a particular motive. For example, in case of theft, the motive for which they commit the act could be retained in the process of individualization of punishment, meaning a general criterion for mitigation or aggravation, given that in the content of indictment only the condition of purpose as an essential feature of the offense can be found.

Moreover, the term "reason" is also used in art. 77 which lists the circumstances which constitute aggravating circumstances, so the last letter " $h$ " of this article refers to committing the offense for reasons of race, nationality, ethnicity, language, religion, gender, sexual orientation, opinion or political affiliation, wealth, social origin, age, disability, non-contagious disease or HIV/AIDS, considered by the offender as causes of inferiority of a person in relation to others.

Even if there have been reported very few cases of application of such circumstances in legal practice, we must not forget that our country has aligned with international legislation on combating all forms of discrimination and committing the act with such a reason reveals an enhanced danger of the offender. It can be noticed that the term "reason" to indicate explicitly these mental processes are a legislative progress from the former Criminal Code where an equivalent term was used, namely "grounds".

\subsection{Special Part of the Criminal Code}

In Title I, Chapter I, devoted to offenses against life, we can notice the qualified version of murder at letter " $b$ " of Article 189, stating that, one of the aggravating circumstances of committing murder is performing it out of "material interests". Material interest has been identified with any advantage, benefit or material gain, followed by committing the offense. 
According to the legislator, committing murder for financial interest is a higher social danger than that of the act in its simple form, as it shows a deeper perversion of conscience of the one trying to satisfy their material interests at any cost, even by taking the life of another.

The legal practice has highlighted the meaning of the expression, stating that any patrimonial motive corresponds with the notion of material interest. Thus, immediate material benefits, obtained through the assimilation of the victim's goods during the murder, do not fall within the definition of financial interest, but within the offense of robbery. Law requirement is fulfilled only if the author acts aiming that by committing murder he satisfies his material interests faster, in an apparently legal manner (for example, by legal or testamentary succession or other similar means which gives a patrimonial character to the victim's goods).

In common language, by interest we understand both the concern in obtaining a benefit or satisfaction of certain needs and benefit, advantage, profit or gain to be obtained. It is obvious that the aggravated murderer must be animated by the motive of the material interest and the offender sees in the victim's death, the only way capable of leading to quick satisfaction of his needs, which cannot be maintained in all situations.

It is not necessary that the reason the murder was committed for had been satisfied to retain this aggravating circumstance. It is sufficient that the act is committed under these psychological processes. Moreover, it is not important whether the offender has wrongly concluded that the victim's death will lead to satisfying the reason. The aggravating circumstance is usually personal and will not affect the participants, but situations where all participants operate under the same motive are not excluded.

Further, in Chapter VI of Title I, entitled "Crimes against personal freedom", in art.
208 par. 1, we find the accusation of harassment and, according to the text, the offense lies in the person's act who repeatedly seeks unrightfully or "without a legitimate interest" a person or monitors his/her home, working place or other places frequented by this person, therefore causing a state of fear. Incrimination seeks to repress the conduct by which a person affects the freedom of another person, through unjustified pursuit.

The essential requirement of the reason is expressed using the equivalent expression "without a legitimate interest", which has the role of negative conditions of existence of the crime. Due to the requirement of the reason, the act can be accomplished only with direct intent.

The offender's justification of a legitimate interest will lead to removing the criminal nature of the act. For example, such a legitimate interest may be invoked by the offender pursuing his ex-wife to whom the children from the marriage were entrusted, since she had neglected them, leaving them often unattended in the home and who does not take care of them, putting them in danger.

In Title III dedicated to offenses on the authority and state borders, we identify at article 257 par. 2 the incrimination of contempt committed out of revenge which consists of an offense against an official who performs a function involving the exercise of state authority or against his assets, for intimidation or revenge, in connection with the performance of work responsibilities. Aggravating circumstantial elements (quality of the passive subject and the purpose or motive of the action) outline an aggravated regulatory variant of the offense committed in the circumstances given.

Although it would seem that the content of incrimination only includes the essential requirement of the purpose, in reality we have the conditions of the reason, for vengeance is the reason causing the offender to act. The grammatical 
interpretation of the text allows us to conclude that the legislator considers revenge, too, as a purpose, although in terms of the actual content of the mental processes, it appears rather as a cause of the crime. Since, also in legal practice, revenge has been constantly considered a despicable reason, we consider that the change of this concept's meaning is unjustified and misleading. This situation could have been avoided by redrafting the text, so that instead of the preposition "for" at the front of the noun "revenge", the preposition "out of" should be used. The requirements of the motive and reason would be expressed in this way in a much clearer way: "for the purpose of intimidation or out of revenge", which would be consistent with the usual meaning of the expressions.

In Title IV dedicated to offenses against justice, we identify the reason's condition in art. 274 which incriminates revenge for helping justice, consisting of a crime against a person or a family member thereof, on the ground that he notified the prosecution authorities, gave evidence or submitted evidence in a criminal or civil case, or in any other proceeding where witnesses are heard. It was considered necessary to introduce this new incrimination, to deter retaliatory acts committed against those who go to court.

The requirement of the reason is expressed explicitly in the content of incrimination using the phrase "on the grounds of" and is also synthetically presented in the marginal term of the offense that refers to it: revenge. In order for this offense to be attributed to the offender, it is necessary to prove the fact that he acted with this reason, otherwise legal classification will be done according to the laws which incriminate that offense.

Rule of article 274 is a norm of reference as it relates to other rules of incrimination, pointing out also that special limits of punishment for any crime committed for this reason is increased by a third.

Another indictment in this title refers to torture which we find described in art. 282 of the Criminal Code. In this case the legislator uses the phrase "for any other reason based on discrimination of any kind", which defines those impulses and tendencies existing in some people to make distinctions between members of society according to criteria that have no justification. The more serious it appears in our legislator's mentality, the conduct of an agent of the public authority or a person acting in an official capacity, to cause the victim pain or strong suffering in contempt, hatred or superiority to some people, thus violating the principle of equality among citizens.

Without explicitly mentioning which those forms of discrimination are, the legislator understands them all, thus adopting an open definition. It does not matter if the discrimination is based on grounds of sex, nationality, race, religion, gender, political affiliation, sexual orientation, beliefs, wealth, social origin, age, disability, noncontagious disease, HIV / AIDS or other. Law requirement is satisfied if the offender acts under the influence of that reason and the reason will be deducted from the external manifestations of the agent. The community police officer will commit the crime of torture for example, after having found a homeless person in the park, finding that this person is part of an ethnic group despised by him, by applying him several kicks.

In Title V, Chapter II is devoted to offenses related to work, and at art. 297 par. 2 we can find a type of abuse of office by limiting certain rights, where the essential requirement of the reason appears in the phrase "based on race, nationality, ethnicity, language, religion, gender, sexual orientation, political affiliation, beliefs, wealth social origin, age, disability, noncontagious disease or HIV / AIDS".

Distinctly incriminating this option of abuse of office, the legislator intended to protect citizens against any attempt of discrimination, no matter who it comes 
from: civil servants or simple natural or legal persons. Incriminating such acts allow citizens to exercise their rights and freedoms without distinction between them. Compared to the typical variant of abuse against the interests of people in paragraph 1 of article 297, the presence of such a reason denotes, according to the legislator's opinion, an infamous and low-minded mental attitude and gives the described act an equally high degree of social danger.

Given that the special reason why acts are committed is part of the very content of incrimination, these crimes would never be committed under statutory aggravating circumstance of article 77 letter $h$ of the Criminal Code.

Regarding the offense of abuse of office in the option of limitation of certain rights, the dominant opinion in the literature is the sense that the act can be committed only with direct intent, because the reason which prompted the offender to move to committing the offense excludes indirect intention or negligence. Contrary opinions have also been expressed, arguing that the deed might also be committed with indirect intention whereas, even animated by such justification, the agent can accept jeopardizing working relations, without actually pursuing this [5]. We have reservations about those claims. In our opinion, the offense cannot be committed but with direct intent because the perpetrator acts with a special intention, qualified by reason. In this case simple intent is not enough, but it must be accompanied by deeper psychological elements related to certain particular impulses, attached to guilt. The author acts with will, knows that he restricts the use or exercise of a person's rights and provides that he thus causes harm to the victim, a result which not only did he had in mind and pursued, but which was also the reason for his action.

\section{References}

[1] Boțian Elisabeta, Mobilul și scopul în dreptul penal, Sibiu, Editura Academiei Forțelor Terestre "Nicolae Bălcescu”, 2011, pp. 30, 32.

[2] Marcu Florin și Maneca Constant, Dicționar de neologisme, București, Editura Academiei, 1978, pp. 695

[3] Cioclei Valerian, Mobilul în conduita criminală, București, Editura All Beck, 1999, pp. 261.

[4] Antoniu George și colaboratorii, Noul Cod penal. Comentarii pe articole, Vol. 2, București, Editura C.H. Beck, 2008, pp. 215-216.

[5] Loghin Octavian și Filipaș Avram, Drept penal, partea specială, București, Editura Didactică și Pedagogică, 1983, pp. 207. 